IZA DP No. 9014

Impacts of the Availability of Old-Age Benefits on Exits from the Labour Market

Ewa Gałecka-Burdziak

Marek Góra

April 2015 


\title{
Impacts of the Availability of Old-Age Benefits on Exits from the Labour Market
}

\author{
Ewa Gałecka-Burdziak \\ Warsaw School of Economics \\ Marek Góra \\ Warsaw School of Economics \\ and IZA
}

\section{Discussion Paper No. 9014 \\ April 2015}

$$
\text { IZA }
$$
P.O. Box 7240
53072 Bonn
Germany

Phone: +49-228-3894-0

Fax: +49-228-3894-180

E-mail: iza@iza.org

Any opinions expressed here are those of the author(s) and not those of IZA. Research published in this series may include views on policy, but the institute itself takes no institutional policy positions. The IZA research network is committed to the IZA Guiding Principles of Research Integrity.

The Institute for the Study of Labor (IZA) in Bonn is a local and virtual international research center and a place of communication between science, politics and business. IZA is an independent nonprofit organization supported by Deutsche Post Foundation. The center is associated with the University of Bonn and offers a stimulating research environment through its international network, workshops and conferences, data service, project support, research visits and doctoral program. IZA engages in (i) original and internationally competitive research in all fields of labor economics, (ii) development of policy concepts, and (iii) dissemination of research results and concepts to the interested public.

IZA Discussion Papers often represent preliminary work and are circulated to encourage discussion. Citation of such a paper should account for its provisional character. A revised version may be available directly from the author. 


\section{ABSTRACT \\ Impacts of the Availability of Old-Age Benefits on Exits from the Labour Market}

Given human longevity, fertility, health and social developments, workers become inactive relatively early throughout Europe. This partially stems from older workers being pushed out of the labour market and from personal motivation to prefer benefits to wages. We focus on this latter effect and analyse whether workers would have stayed active had they not been tempted by the availability of the old-age benefits. We focus on Poland, a country severely experiencing the problem of population ageing. In 2013 persons 50+ accounted for $37 \%$ of the total population. Although they enjoy a relatively low unemployment rate, their participation and employment rates are very low: $34 \%$ and $32 \%$, respectively. We analyse whether this is due to the discouraged worker effect. We identify the cyclical properties of activity and discouraged worker rates, and estimate a set of logistic regressions to identify the determinants of the exits from the labour market. Cyclical analysis indicates that the added worker effect prevails over the discouraged worker effect. The discouraged worker effect appears with a delay of a few quarters. The process is asymmetric for females. Workers often permanently leave the market. The availability of old-age benefits increases the probability of outflow from unemployment to inactivity, as do unemployment rate changes. If old-age benefits become the main source of income for the worker within the 1 year interval, they are 8 to 20 times more likely to leave the workforce compared to those who receive either unemployment benefits or social welfare benefits.

JEL Classification: J14, J22

Keywords: discouraged workers, discouraged worker effect, exits from the labour market, unemployment outflow, inflow to inactivity, old-age benefits

Corresponding author:

Marek Góra

Warsaw School of Economics (SGH)

Aleja Niepodleglosci 162

02-554 Warszawa

Poland

E-mail: marek.gora@sgh.waw.pl

\footnotetext{
* Article prepared within a project financed by the National Science Centre Poland, project no. DEC2012/05/N/HS4/00194. Ewa Gałecka-Burdziak is a "START" Scholarship holder granted by the Foundation for Polish Science (FNP).
} 


\section{Introduction}

Activity rates among persons aged $50+$ in Poland are on average low compared to demographic characteristics observed in Europe in the $21^{\text {st }}$ century. This early exit from the labour market may be attributed to a number of reasons. (i) Labour market institutions are designed according to absolute age limits, while, for instance, retirement at 65 means a totally different situation for a worker than a century ago. (ii) Employers use retirement as a cheap and easy means to restructure staff, and view it as a subsidy. (iii) Politicians eagerly modify the retirement age, although today considerably rarely due to budgetary problems. (iv) Due to the "lump of labour fallacy" many people (probably the vast majority of them) assume that the number of jobs is fixed, and so the retirement of older workers should improve the situation of younger workers (e.g. see Saint-Paul (2004)). (v) Workers are motivated to retire earlier rather than later; in the majority of developed countries social security provisions place heavy taxes on work beyond the earliest retirement age (see for instance Gruber and Wise (1999)). (vi) Workers are motivated to retire earlier rather than later, as this is perceived as a way of escaping the income-leisure trade-off.

In this paper we focus on the last factor only, i.e. the demotivation effect generated by the availability of old-age benefits before workers are at an age where they are really unable to earn on their own. This statement may be perceived as too strong; it does not take into account various social dimensions either. However, if we assume that workers should start receiving old-age benefits much earlier than actual old age (when people are no longer able to earn on their own), we neglect the interest of young workers whose remuneration would have to finance this policy (see Góra 2013). In this paper we do not discuss social policy or political economy. Instead, we ask the following question: to what extent does easy and early access to old-age benefits contribute to the widely observed low activity rates of 
older workers. We try to answer this question by analysing exits from the labour force in the framework of work discouragement.

The discouraged worker effect (due to job market-related reasons) implies that activity rates ${ }^{1}$ are either pro-cyclical ${ }^{2}$ with respect to GDP or counter-cyclical with respect to the unemployment rate (or other respective macroeconomic indicators). In the microeconomic perspective, research most often identifies the determinants of labour market status of workers. Van Ham et al. (2001) look for discouragement at two stages of the search and matching process. Discouragement can arise when an individual who decides on economic activity moves into inactivity as a way of evading unemployment. The second stage of potential discouragement refers to job search intensity; workers with lower employability seek work less intensively.

Some analyses concern the behaviour of older workers in the labour market, for example Benitez-Silva (2002) proposes a formal dynamic model of job search. These persons are likely to remain active in the labour market beyond the traditional retirement age. They actively seek work, both on the job and when not employed, but the job search behaviour depends on the previous work attachment and health conditions. Darby et al. (1998) and O'Brien (2011) analyse cyclical properties of participation rates. Darby et al. (1998) find that the discouraged worker effect is especially common among females aged 45-54. O'Brien (2011) $\operatorname{argues}^{3}$ that the activity rates of older males are influenced by the business cycle. In both analyses the effect is asymmetric in nature. The influence from the cyclical downturn in participation rates dominates over the increase in participation rates induced by economic recovery. Maestas and Li (2006) analyse the search behaviour of older not employed workers

\footnotetext{
${ }^{1}$ Compare Benati (2001) for a literature survey on methods used in the aggregate analyses.

${ }^{2}$ Cyclical properties of the activity rates can be disturbed if the worker flows are persistent (Clark and Summers 1982).

${ }^{3}$ O'Brien (2011) also argues that the influence of a social security pension value on participation rates is relatively small.
} 
and report relatively low transition rates as only half of the older job-seekers find work. $13 \%$ can be classified as discouraged workers ${ }^{4}$, while the remainder, experiencing either health or income shocks, make little job search effort or their reservation wages are relatively high.

We base our analysis on the Polish labour market data. This choice stems from a number of reasons. In Poland it is prohibited to fire a worker once they reach retirement age. The traditional version of this age has been replaced by the so-called minimum retirement age. A worker can go to a court and sue the employer for firing them if the worker is above the minimum retirement age. Old-age benefits are calculated on the basis of the present value of paid contributions and the age at which the benefits begin to be paid out. This amount reduces or can even negate the level of tax on further work. These regulations, introduced with the pension reform in 1999, came into effect for those retiring around 2008 and have just begun to influence the situation in the Polish labour market. Although they have not yet become strong factors behind retirement decisions, the data show a recent increase in activity rates and the actual retirement age in Poland (see Eurostat).

In section 2 we present a quantitative analysis of the discouraged worker effect in both macroeconomic and microeconomic perspectives. We present cross-correlations between the cyclical components of the analysed variables and the selected macroeconomic indicators. We look for asymmetry in the adjustment process of the relationship between either the activity rate or the discouraged worker rate and the unemployment rate. We approximate the discouraged worker effect by the outflow from unemployment to inactivity and we identify the factors that make older workers more willing to withdraw from job search. We focus on the role of old-age benefits and job-finding opportunities. In section 3 we discuss the results, while in section 4 we present our conclusions.

\footnotetext{
${ }^{4}$ By discouraged workers Maestas and Li (2006) mean those job seekers who are willing to work at the prevailing wage rate but are unable to find a job.
} 


\section{Quantitative findings}

Empirical analysis refers to the population in Poland aged 50+. Poland faces low participation rates (34\% in 2013 for persons 50+) accompanied by a low actual retirement age (in 2013 the average age of new beneficiaries was less than 60 for both males and females). Around $3 \%$ of those $50+$ indicate that retirement is the main reason for not looking for employment. For 57.5\% of those aged 50-69 who are inactive and receive old-age benefits, reaching eligibility for the benefits is the main reason for quitting work ${ }^{5}$ (LFS data for 2012). Simultaneously, $50 \%$ of those receiving old-age benefits who decide to continue working indicate the main reason is to provide sufficient personal/household income (LFS data for 2012). We base the quantitative analysis on aggregate and microeconomic data from LFS.

\subsection{Cyclical properties of the participation and discouraged worker rates}

We use the aggregate data of the activity rates and discouraged worker rates ${ }^{6}$ for the time period 2000-2013. We focus on the following age groups: males either 45-64 or 45+, and females either 45-59 or 45+. The macroeconomic indicators used for reference comprise the gross domestic product (GDP, in millions of PLN, chain linked volumes, reference year 2005) and unemployment rate.

The average activity rate for males aged 45-64 equals $0.662 \pm 0.014$ and decreases to $0.495 \pm 0.008$ for males $45+$. For females aged $45-59$ the average participation rate equals $0.604 \pm 0.036$ and decreases to $0.331 \pm 0.011$ for females aged $45+$. Discouraged worker rates are higher for the subsample of the working age population, at 0.024 and 0.018 for males and 0.037 and 0.034 for females. All series display a high degree of persistence. Monthly autocorrelation coefficients are higher for the participation rates than for the discouraged worker rates. The summary statistics for the selected variables are presented in

\footnotetext{
${ }^{5}$ An analogous conclusion arises from SHARE analysis. Moreover, the health status has only a minor impact on the decision of when to leave the labour force (Myck et al. 2014).

${ }^{6}$ By the discouraged worker rate we mean the ratio of the number of discouraged workers to the population.
} 
Table 9 in the Appendix. The unit root existence and stationarity of the series are verified using ADF, KPSS and Phillips-Perron tests (see Table 1). The tests' results indicate that the analysed time series are $\mathrm{I}(1)$.

Table 1. ADF, Phillips-Perron and KPSS tests statistics.

\begin{tabular}{|c|c|c|c|}
\hline Variable & $\mathrm{ADF}$ & $\begin{array}{c}\text { Test statistics } \\
\text { Phillips-Perron } \\
\end{array}$ & KPSS \\
\hline & \multicolumn{3}{|c|}{$\mathrm{I}(1)$ vs. I(2) } \\
\hline male activity rate $45-64$ & -7.760 & -7.760 & 0.126 \\
\hline male activity rate $45+$ & -6.422 & -6.453 & 0.077 \\
\hline female activity rate $45-59$ & -5.546 & -5.704 & 0.606 \\
\hline female activity rate $45+$ & -7.980 & -8.044 & 0.208 \\
\hline $\begin{array}{l}\text { male discouraged worker } \\
\text { rate } 45-64\end{array}$ & -7.729 & -7.857 & 0.076 \\
\hline $\begin{array}{l}\text { male discouraged worker } \\
\text { rate } 45+\end{array}$ & -8.141 & -8.361 & 0.091 \\
\hline $\begin{array}{l}\text { female discouraged } \\
\text { worker rate } 45-59\end{array}$ & -6.754 & -6.754 & 0.068 \\
\hline $\begin{array}{l}\text { female discouraged } \\
\text { worker rate } 45+\end{array}$ & -6.491 & -6.491 & 0.084 \\
\hline GDP & $-5.533^{\mathrm{a}}$ & -3.129 & 0.171 \\
\hline \multirow[t]{2}{*}{ unemployment rate } & -2.131 & -3.989 & 0.167 \\
\hline & \multicolumn{3}{|c|}{$\mathrm{I}(0)$ vs. I(1) } \\
\hline male activity rate $45-64$ & -0.260 & -0.217 & 0.868 \\
\hline male activity rate $45+$ & -0.956 & -1.294 & 0.618 \\
\hline female activity rate $45-59$ & 1.031 & 0.449 & 0.384 \\
\hline female activity rate $45+$ & -1.688 & -1.613 & 0.217 \\
\hline $\begin{array}{l}\text { male discouraged worker } \\
\text { rate } 45-64\end{array}$ & -2.524 & -2.524 & 0.148 \\
\hline $\begin{array}{l}\text { male discouraged worker } \\
\text { rate } 45+\end{array}$ & -2.682 & -2.696 & 0.141 \\
\hline $\begin{array}{l}\text { female discouraged } \\
\text { worker rate } 45-59\end{array}$ & -1.709 & -1.773 & 0.578 \\
\hline $\begin{array}{l}\text { female discouraged } \\
\text { worker rate } 45+\end{array}$ & -1.595 & -1.702 & 0.385 \\
\hline GDP & 0.538 & 0.280 & 0.895 \\
\hline unemployment rate & -1.320 & -0.829 & 0.661 \\
\hline
\end{tabular}

Source: authors' calculations.

Below we test for the relationship between the respective activity rates, discouraged worker rates and the variables that characterize the macroeconomic situation. We apply a band-pass Christiano-Fitzgerald filter and high-pass Hodrick-Prescott filter and compute the correlation coefficients between the cyclical components of the particular series (see Table 2).

Most of the coefficients imply that the activity rates are counter-cyclical with respect to the 
GDP or pro-cyclical with respect to the unemployment rate. The discouraged worker rates show contrary correlations. The qualitative inference is broadened when we look at lags. Statistically significant correlation coefficients of the expected sign arise between (see Table 10 in the Appendix): (i) female activity rates and GDP lagged by 10 periods or more, (ii) female activity rates and unemployment rate lagged by 7 periods or more, (iii) male discouraged worker rates and GDP by lagged 2 periods or more, (iv) 45+ female discouraged worker rate and GDP lagged by 9 periods or more, (v) male discouraged worker rates and the unemployment rate lagged by 2 periods or more and (vi) $45+$ female discouraged worker rate and the unemployment rate lagged by 5 periods or more.

Table 2. Correlation coefficients between cyclical components of the male and female activity rates, male and female discouraged workers rates, GDP and unemployment rate computed on the basis of the CF and HP filters estimates.

\begin{tabular}{|c|c|c|c|c|}
\hline \multirow[b]{2}{*}{ Variable } & \multicolumn{2}{|c|}{ Christiano-Fitzgerald filter } & \multicolumn{2}{|c|}{ Hodrick-Prescott filter } \\
\hline & GDP & $\begin{array}{l}\text { unemployment } \\
\text { rate }\end{array}$ & GDP & $\begin{array}{l}\text { unemployment } \\
\text { rate }\end{array}$ \\
\hline male activity rate $45-64$ & $-0.326^{*}$ & 0.259 & -0.079 & 0.048 \\
\hline male activity rate $45+$ & -0.699 & 0.206 & 0.190 & 0.031 \\
\hline female activity rate $45-59$ & $-0.443 * *$ & $0.541 * * *$ & $-0.364 * * *$ & $0.545 * * *$ \\
\hline female activity rate $45+$ & $-0.326^{*}$ & $0.500 * * *$ & -0.207 & $0.491 * * *$ \\
\hline male discouraged worker rate $45-64$ & $0.308^{*}$ & -0.183 & $-0.305^{* *}$ & $0.251 *$ \\
\hline male discouraged worker rate $45+$ & $0.345^{*}$ & -0.200 & $-0.327 * *$ & $0.270 * *$ \\
\hline female discouraged worker rate $45-59$ & 0.028 & -0.045 & -0.122 & 0.091 \\
\hline female discouraged worker rate $45+$ & -0.010 & -0.007 & -0.174 & 0.134 \\
\hline
\end{tabular}

* - significant at the 10 per cent level, ** - significant at the 5 per cent level, *** - significant at the 1 per cent level.

Source: authors' calculations.

Next we search for the relationship between either the activity rate or discouraged worker rate and the macroeconomic indicator. We seek a long-term relationship and test for potential asymmetry in the adjustment process. Two interesting results arise (see Table 3). There is an interdependence between the female activity rate (for $45+$ females) and unemployment rate lagged by 10-periods:

$$
\text { female activity rate } \left.\text { f }_{t} \text { for females } 45+\right)=\alpha_{0}+\alpha_{1} \text { unemployment rate } \text { f }_{t-10}+\varepsilon_{t}
$$

There is also a relationship between the male discouraged worker rate (for $45+$ males) and the unemployment rate for males $45+$ lagged by 5 periods: 
male discouraged worker rate ${ }_{t}($ for males $45+)$

$$
=\alpha_{0}+\alpha_{1} \text { unemployment rate }(\text { for males } 45+)_{t-5}+\varepsilon_{t}
$$

The equations define stable long-term relationships. In both specifications the residuals suffer from autocorrelation but once the $\mathrm{AR}(1)$ term is added the coefficient estimates do not differ significantly ${ }^{7}$. The models approach a new equilibrium within 4 or 2 quarters respectively. The coefficients of the positive and negative correction terms differ. In the case of the female activity rate equation, the coefficient standing next to $\hat{\varepsilon}_{t}^{+}$is not statistically different from 0 . The coefficient of $\hat{\varepsilon}_{t-1}^{-}$implies the equation after the negative shock returns to equilibrium within around 2.5 quarters. The Wald test statistics at $10 \%$ significance level allows stating that these coefficients differ.

The equation that allows asymmetry simultaneously in the short- and the long-term (for females) provides more detailed results. Regular ECM estimates show that in the shortterm the changes in unemployment rate have an opposite impact to the long-term changes. The unemployment rate deviation implies a one-directional change in the activity rate, but once the deviations are split it appears that only the negative change in unemployment rate implies a decrease in the activity rate. The positive deviation has statistically insignificant coefficient. The model returns to equilibrium within 1.5 quarters after the negative shock. The Wald test statistics at $1 \%$ significance level allows rejecting the null hypothesis of coefficients equivalence. The Wald test statistics at 5\% significance level allows concluding that the coefficients of $\Delta$ unemployment rate $^{+}$and $\Delta$ unemployment rate $^{-}$differ. The respective coefficients of the correction terms in the case of the male discouraged worker rate differ, but not statistically significantly.

\footnotetext{
${ }^{7} \hat{\alpha}_{1}$ in the female activity rate equation p-value is just above 0.05 .
} 
Table 3. Female activity rate regressed on the lagged unemployment rate, and male discouraged worker rate regressed on the lagged male unemployment rate, long-term, ECM and asymmetric ECM estimates results.

\begin{tabular}{|c|c|c|c|c|}
\hline & \multicolumn{2}{|c|}{ Female activity rate $(45+)$} & \multicolumn{2}{|c|}{ Male discouraged worker rate $(45+)$} \\
\hline & coefficient & standard error & coefficient & standard error \\
\hline & \multicolumn{4}{|c|}{ Long-term relationship } \\
\hline unemployment rate $e_{-10}$ & $-0.129 * * *$ & 0.025 & & \\
\hline unemployment rate $_{-5}$ (males $\left.45+\right)$ & & & $0.039 * * *$ & 0.009 \\
\hline $\bar{R}^{2}$ & 0.360 & & 0.286 & \\
\hline LM (p-value) & $41.295(0.00)$ & & $14.94(0.00)$ & \\
\hline \multirow[t]{2}{*}{$\mathrm{ADF}(\mathrm{p}$-value) } & $-2.172(0.03)$ & & $-3.290(0.00)$ & \\
\hline & \multicolumn{4}{|c|}{ Error Correction Model } \\
\hline sunemployment rate & $0.240 * *$ & 0.100 & & \\
\hline sunemployment rate $_{-3}$ (males $45+$ ) & & & $-0.081 * *$ & 0.035 \\
\hline$\hat{\varepsilon}_{t-1}$ & $-0.267 * * *$ & 0.080 & $-0.449 * * *$ & 0.108 \\
\hline $\bar{R}^{2}$ & 0.247 & & 0.280 & \\
\hline LM (p-value) & $2.281(0.12)$ & & $1.065(0.35)$ & \\
\hline \multirow[t]{2}{*}{$\mathrm{ADF}$ (p-value) } & $-5.951(0.00)$ & & $-6.214(0.00)$ & \\
\hline & \multicolumn{4}{|c|}{ Error Correction Model - long-term asymmetry } \\
\hline sunemployment rate & $0.324 * * *$ & 0.109 & & \\
\hline$\Delta_{\text {unemployment rate }}-3$ (males $45+$ ) & & & $-0.077 * *$ & 0.036 \\
\hline$\hat{\varepsilon}_{t-1}^{+}$ & -0.104 & 0.123 & $-0.376^{* *}$ & 0.154 \\
\hline$\hat{\varepsilon}_{t-1}^{-1}$ & $-0.404 * * *$ & 0.112 & $-0.521 * * *$ & 0.152 \\
\hline $\bar{R}^{2-1}$ & 0.280 & & 0.271 & \\
\hline LM (p-value) & $2.00(0.15)$ & & $0.769(0.47)$ & \\
\hline ADF (p-value) & $-7.30(0.00)$ & & $-6.352(0.00)$ & \\
\hline \multirow[t]{2}{*}{ Wald test long-term asymmetry ( $\mathrm{p}$-value) } & $1.71(0.095)$ & & $0.669(0.51)$ & \\
\hline & \multicolumn{4}{|c|}{ Error Correction Model - short-term and long-term asymmetry } \\
\hline Dunemployment rate ${ }^{+}$ & -0.214 & 0.238 & & \\
\hline Dunemployment rate - $^{-}$ & $0.636^{* * *}$ & 0.161 & & \\
\hline Dunemployment rate ${ }_{-3}^{+}$(males $\left.45+\right)$ & & & -0.068 & 0.058 \\
\hline Dunemployment rate -3 (males $45+$ ) & & & 0.013 & 0.233 \\
\hline$\hat{\varepsilon}_{t-1}^{+}$ & 0.108 & 0.144 & -0.263 & 0.194 \\
\hline$\hat{\varepsilon}_{t-1}^{-1}$ & $-0.651 * * *$ & 0.144 & $-0.536^{* * *}$ & 0.159 \\
\hline $\bar{R}^{2}$ & 0.361 & & 0.206 & \\
\hline LM (2 lags) (p-value) & $1.003(0.38)$ & & $0.109(0.90)$ & \\
\hline $\mathrm{ADF}(\mathrm{p}$-value $)$ & $-6.697(0.00)$ & & $-6.792(0.00)$ & \\
\hline Wald test short-term asymmetry ( $\mathrm{p}$-value) & $-2.514(0.02)$ & & $-0.983(0.33)$ & \\
\hline Wald test long-term asymmetry ( $\mathrm{p}$-value) & $3.080(0.00)$ & & $1.080(0.29)$ & \\
\hline
\end{tabular}

Source: authors' calculations.

The asymmetry in the adjustment process, implied by the asymmetric ECM model for the female activity rate, is further verified by estimating the TAR-ECM and M-TAR ECM specifications (Enders and Granger 1998; Enders and Siklos 2001). The threshold is either assumed $\tau=0$ or estimated. Only the M-TAR specification with the estimated value of the threshold at -0.0024 provides statistically significant results (see Table 4). The threshold cointegration test t-Max implies that the variables are not cointegrated, but the alternative test $\rho_{1}=\rho_{2}=0$ leads to a contrary conclusion. Enders and Siklos (2001) show that the second 
test can have more power compared to the first one. Threshold cointegration is implied by the $\rho_{1}=\rho_{2}$ hypothesis results. The model reverts faster to equilibrium after the negative impulse.

Table 4. The results of the threshold cointegration tests for the female activity rate.

\begin{tabular}{lcccc}
\hline & \multicolumn{4}{c}{ Female activity rate $(45+)$} \\
\hline Parameter, & \multicolumn{4}{c}{ Pattern of adjustment } \\
\cline { 2 - 5 } Hypotheses & 0 & TAR & -0.0097 & M-TAR \\
\hline$\tau$ & -0.185 & -0.086 & $0.114)$ & -0.0024 \\
$\rho_{1}$ (above threshold) & $(0.147)$ & -0.359 & $(0.123)$ & 0.005 \\
& -0.116 & $(0.214)$ & $-0.386^{* *}$ & $(0.096)$ \\
$\rho_{2}$ (below threshold) & $(0.133)$ & 1.257 & $(0.161)$ & $-0.813^{* * *}$ \\
$\rho_{1}=\rho_{2}$ & 0.130 & -0.757 & $3.491^{*}$ & $13.461)$ \\
t-Max value & -0.874 & 1.706 & -0.058 & 0.048 \\
$\rho_{1}=\rho_{2}=0$ & 1.110 & 2.886 & $8.152^{*}$ \\
\hline$*$ - significant at the 10 per cent level, ** - significant at the 5 per cent level, *** - significant at the 1 per cent level. Standard \\
errors reported in parentheses.
\end{tabular}

Source: authors' calculation.

Apart from the asymmetry in the length of the adjustment process, we analyse the asymmetry in the size of the discouraged worker effect along the business cycle according to the solutions proposed by Darby et al. (1998) and O'Brien (2011). The first paper defines the dummy variable of the value 1 from the period when the cyclical component of GDP reaches a peak until the trough and zero elsewhere. The dummy variable coefficient estimate is not statistically significant, which implies that the influences from the cyclical downturn or the economic recovery are comparable in size.

O'Brien (2011) follows Connolly (1997). The framework defines the following variables:

$\Delta$ unemployment rate ${ }^{+}=\Delta$ unemployment rate if $\Delta$ unemployment rate $>0$ and 0 otherwise,

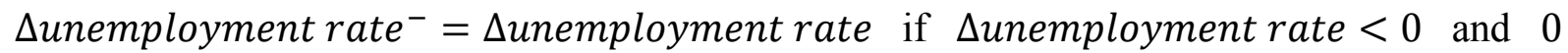
otherwise.

The two variables present the cumulated positive and negative changes in the unemployment rate:

$$
\text { cumulated }_{t}^{+}=\text {cumulated }_{t-1}^{+}+\Delta \text { unemployment } \text { rate }_{t}^{+}
$$




$$
\text { cumulated }_{t}^{-}=\text {cumulated }_{t-1}^{-}+\Delta \text { unemployment } \text { rate }_{t}^{-}
$$

Asymmetry arises when the coefficients of the cumulated responses differ significantly. We estimate the equation of the male discouraged worker rate $(45+)$.

Table 5. Model results allowing asymmetry in the discouraged worker effect.

\begin{tabular}{|c|c|c|}
\hline \multicolumn{3}{|c|}{ Male discouraged worker rate $(45+)$} \\
\hline & coefficient & standard error \\
\hline intercept & $0.016^{* * *}$ & 0.001 \\
\hline cumulated $^{+}$ & $0.014 * *$ & 0.006 \\
\hline cumulated $^{-}$ & $0.006 * *$ & 0.002 \\
\hline$\rho$ & $0.641 * * *$ & 0.111 \\
\hline $\bar{R}^{2}$ & 0.574 & \\
\hline $\mathrm{ADF}$ (p-value) & $-6.869(0.00)$ & \\
\hline Wald test for the asymmetry response (p-value) & $1.842(0.07)$ & \\
\hline
\end{tabular}

Source: authors' calculations.

Estimation results (see Table 5) indicate that the male discouraged worker rate experiences asymmetric responses to the cyclical fluctuations. At $10 \%$ significance level the Wald test statistics imply that the increase in the male discouraged worker ratio $(45+)$ in a recession is larger than the decrease during an economic recovery.

\subsection{What factors discourage workers from the job search?}

In this subsection we analyse the participation in the labour force. We want to identify the factors that make workers more likely to leave the labour market. We broaden the standard definition of the discouraged worker effect to identify the role of the impact of oldage benefits on job search activity. We treat these benefits as an alternative source of income, either already available to the workers or as a forthcoming income option to those who would soon become eligible for the benefits. We want to determine to what extent the old-age benefits discourage workers from active job search. In this manner, we focus on the flow from unemployment to inactivity (as an approximation of the discouraged worker effect). We base the quantitative analysis on individual yearly LFS data for the period 2004-2010. We refer either to workers aged 50-59 (females) and 50-64 (males) or to workers aged 50+ (females 
and males). The whole sample consisted of more than 5000 individuals, $34 \%$ of which withdrew from job search within the 1 year interval. If we narrow the sample to the working age population, $33 \%$ of more than 5000 individuals moved from unemployment to inactivity. Males constituted $57 \%$ of the whole sample. Around $1 / 4$ of the workers indicated old-age benefits as a source of income in $t_{0}$ while for $12 \%$ this benefit was the main source of income. Almost half of the workers sought work for 13 months or more and $2 / 3$ of the workers had vocational or primary education. The distribution of either the duration of unemployment or the educational level did not significantly differ among those who moved from unemployment to inactivity or for those who remained unemployed.

Tables 6-8 provide the results of the labour force participation analysis. By discouraged workers we mean those who stopped seeking a job during the 1 year interval. We analyse the impact of old-age benefits and job finding opportunities on the discouragement from job search. In the first case, we analyse changes in the status of those receiving old-age benefits in $t_{0}$ (Table 6). Females and older workers show a higher probability of leaving the labour force. In both models a positive change in the unemployment rate increases the probability of withdrawal from job search.

Next, we look at the participation decisions of the workers, regardless of whether they received old-age benefits in $t_{0}$ or not (see Table 7). Similar conclusions arise: females and older workers are more willing to move from unemployment to inactivity. An increase in the unemployment rate, approximating decreasing job finding opportunities, raises the probability of discouragement among older workers. If the old-age benefits constituted any source of income in $t_{1}$, the workers were more than twice as likely to withdraw from job search.

Finally, we directly identify the impact of old-age benefits by looking at the workers who did not receive any kind of old-age benefits in $t_{0}$ (see Table 8). Analogously, females 
and older workers were more likely to leave the labour force. An increase in the unemployment rate raised the probability of discouragement among older workers. If the oldage benefit became a source of income in $t_{1}$, the workers were 4.7 times more likely to move from unemployment to inactivity. When we differentiate the main sources of income in $t_{1}$, the workers who received old-age benefits were 8 times more likely to leave the workforce than those receiving unemployment benefits in $t_{1}$ and even 20 times more likely to leave the workforce than those receiving social welfare benefits in $t_{1}$.

Table 6. Logistic regression of moving from unemployment to inactivity for workers receiving old-age benefits in $t_{0}$.

\begin{tabular}{|c|c|c|c|c|}
\hline \multicolumn{5}{|c|}{ Workers receiving the old-age benefits in $t_{0}$} \\
\hline & odds ratio & standard error & odds ratio & standard error \\
\hline \multicolumn{5}{|l|}{ Age (years): } \\
\hline $50-54$ & 1 & & 1 & \\
\hline $55-59$ & $1.747 * * *$ & 0.268 & $1.748^{* *}$ & 0.267 \\
\hline $60-64$ & $4.094 * * *$ & 1.342 & $3.746 * * *$ & 0.887 \\
\hline$>65$ & & & $3.068 * * *$ & 1.050 \\
\hline \multicolumn{5}{|l|}{ Sex: } \\
\hline Males & 1 & & 1 & \\
\hline Females & $1.441^{* *}$ & 0.211 & $1.460 * * *$ & 0.198 \\
\hline Dunemployment rate & $5.84 \mathrm{E}-9 * * *$ & $2.79 \mathrm{E}-8$ & $5.45 \mathrm{E}-7 * * *$ & $2.48 \mathrm{E}-6$ \\
\hline Log likelihood & -582.66 & & -640.32 & \\
\hline LR & $42.95(\mathrm{df}=4)$ & & $57.99(\mathrm{df}=5)$ & \\
\hline p-value & 0.00 & & 0.00 & \\
\hline McFadden's Adj $R^{2}$ & 0.036 & & 0.043 & \\
\hline Sensitivity & $16.31 \%$ & & $25.20 \%$ & \\
\hline Specificity & $93.79 \%$ & & $89.98 \%$ & \\
\hline Correctly classified & $66.13 \%$ & & $65.54 \%$ & \\
\hline
\end{tabular}

\section{Source: authors' calculations.}


Table 7. Logistic regression of moving from unemployment to inactivity for the workers receiving or not receiving the old-age benefits in $t_{0}$

\begin{tabular}{|c|c|c|c|c|}
\hline \multicolumn{5}{|c|}{ Workers receiving or not receiving the old-age benefits in $t_{0}$} \\
\hline & odds ratio & standard error & odds ratio & standard error \\
\hline \multicolumn{5}{|l|}{ Age (years): } \\
\hline $50-54$ & 1 & & 1 & \\
\hline $55-59$ & $2.135 * * *$ & 0.213 & $2.102 * * *$ & 0.208 \\
\hline $60-64$ & $6.593 * * *$ & 1.469 & $4.602 * * *$ & 0.840 \\
\hline$>65$ & & & $2.974 * * *$ & 1.014 \\
\hline \multicolumn{5}{|l|}{ Sex: } \\
\hline Males & 1 & & 1 & \\
\hline Females & $1.607 * * *$ & 0.151 & $1.519 * * *$ & 0.137 \\
\hline sunemployment rate & $3.27 \mathrm{E}-15 * * *$ & $1.04 \mathrm{E}-14$ & $4.78 \mathrm{E}-14 * * *$ & $1.48 \mathrm{E}-13$ \\
\hline \multicolumn{5}{|c|}{$\begin{array}{l}\text { Old-age benefits as a source of } \\
\text { income in } t_{1} \text { : }\end{array}$} \\
\hline $\mathrm{NO}$ & 1 & & 1 & \\
\hline YES & $2.285 * * *$ & 0.236 & $2.284 * * *$ & 0.231 \\
\hline Log likelihood & -1471.27 & & -1539.94 & \\
\hline LR & $276.51(\mathrm{df}=5)$ & & $296.78(\mathrm{df}=6)$ & \\
\hline p-value & 0.00 & & 0.00 & \\
\hline McFadden's Adj $R^{2}$ & 0.082 & & 0.088 & \\
\hline Sensitivity & $20.41 \%$ & & $23.22 \%$ & \\
\hline Specificity & $95.32 \%$ & & $94.03 \%$ & \\
\hline Correctly classified & $73.65 \%$ & & $72.88 \%$ & \\
\hline
\end{tabular}

\section{Source: authors' calculations.}


Table 8. Logistic regression of moving from unemployment to inactivity for workers not receiving any kind of old-age benefits in $t_{0}$.

\begin{tabular}{|c|c|c|c|c|}
\hline \multicolumn{5}{|c|}{ Workers not receiving any kind of old-age benefits in $t_{0}$} \\
\hline & odds ratio & standard error & odds ratio & standard error \\
\hline \multicolumn{5}{|l|}{ Age (years): } \\
\hline $50-54$ & 1 & & 1 & \\
\hline $55-59$ & $2.607 * * *$ & 0.343 & $2.106 * * *$ & 0.289 \\
\hline $60-64$ & $9.713 * * *$ & 2.952 & $7.763 * * *$ & 2.387 \\
\hline \multicolumn{5}{|l|}{ Sex: } \\
\hline Males & 1 & & 1 & \\
\hline Females & $1.733 * * *$ & 0.216 & $1.816 * * *$ & 0.235 \\
\hline sunemployment rate & $1.74 \mathrm{E}-16 * * *$ & $7.14 \mathrm{E}-16$ & $3.26 \mathrm{E}-13 * * *$ & $1.36 \mathrm{E}-12$ \\
\hline \multicolumn{5}{|c|}{$\begin{array}{l}\text { Old-age benefits as a source of } \\
\text { income in } t_{1} \text { : }\end{array}$} \\
\hline NO & 1 & & & \\
\hline YES & $4.714 * * *$ & 1.023 & & \\
\hline \multicolumn{5}{|c|}{ Main source of income in $t_{1}$ : } \\
\hline Old-age benefits $^{\mathrm{a}}$ & & & 1 & \\
\hline Unemployment benefit & & & $0.121 * * *$ & 0.070 \\
\hline Social welfare $^{\mathrm{b}}$ & & & $0.048 * * *$ & 0.021 \\
\hline Invalidity allowance & & & $0.155 * * *$ & 0.072 \\
\hline Log likelihood & -874.51 & & -841.02 & \\
\hline LR & $230.57(\mathrm{df}=5)$ & & $297.54(\mathrm{df}=7)$ & \\
\hline p-value & 0.00 & & 0.00 & \\
\hline McFadden's Adj $R^{2}$ & 0.110 & & 0.142 & \\
\hline Sensitivity & $19.86 \%$ & & $26.86 \%$ & \\
\hline Specificity & $97.47 \%$ & & $95.94 \%$ & \\
\hline Correctly classified & $77.82 \%$ & & $78.44 \%$ & \\
\hline
\end{tabular}

Notes: ${ }^{\text {a }}$ - old-age benefits - pension or retirement benefits, ${ }^{b}$ - social welfare - social benefit, non-income source, dependent. * - significant at the 10 per cent level, ** - significant at the 5 per cent level, *** - significant at the 1 per cent level. The sample comprises individuals aged either 50-59 (females) and 50-64 (males) or workers aged 50+, yearly data for the period 2004-2010. Sample size for both models - 1749 observations.

Source: authors' calculations.

Separate considerations refer to employed workers. For almost $15 \%$ of the employed workers, the old-age benefits constituted a source of income, for $13 \%$ of the employed workers the old-age benefits were the main source of income. Around $7 \%$ of the employed workers in $t_{0}$ moved to inactivity in $t_{1}$, and $59 \%$ of those workers claimed they did not seek work because they received old-age benefits. Simple logistic regressions show that changes in the unemployment rate increased the probability of moving from employment to inactivity. The models experience poor statistical properties, though. We have been unable to identify any other factors that statistically significantly describe the flow of workers from employment 
to inactivity within the 1 year interval that could imply the existence of a discouraged worker effect.

\section{Discussion}

The results provide some interesting conclusions. In a macroeconomic perspective it appears that the added worker effect prevails over the discouraged worker effect. The second effect arises after some delay. When economic conditions worsen, workers at first increase their job search activity, most probably to compensate for the decrease in household income. As time elapses they become discouraged with the unsuccessful job search and leave the labour market. The substantial delay can be also partially explained by the inertia in the labour market and the fact that it takes time until a new equilibrium is reached.

ECM estimates provide comparable conclusions. The discouraged worker effect arises once we analyse the unemployment rate lagged by 5 to 10 quarters. In the short-term the added worker effect prevails. More detailed analysis (of the split in unemployment rate deviations) implies that a negative change in the unemployment rate induces a decrease in the activity rate. It seems that when job-finding opportunities improve, some workers become 'lazy' and do not take part in the search and matching process ${ }^{8}$.

Asymmetry arises in both the magnitude of the reaction and the length of the adjustment process. The market returns much faster to a long-term equilibrium in the case of a negative shock to the unemployment rate. The increase in the activity rate induced by the improved conditions in the market is only temporary. On the other hand, once the unemployment rate increases, females leave the market almost permanently. Consistent qualitative conclusions arise from the asymmetric ECM and threshold ECM estimates.

The male discouraged worker rate model shows, in turn, that the response of the discouraged worker rate is larger during recessions than during expansions. More males

\footnotetext{
${ }^{8}$ Gałecka-Burdziak and Pater (2014) draw analogous conclusions with respect to the working age population.
} 
decide to leave the market when job finding opportunities decrease, compared to the number of those who start actively looking for a job once the employment finding chances improve.

All the logistic regression model estimates show that the females and older workers are more likely to leave the workforce. The outflow from unemployment to inactivity is susceptible to business cycle fluctuations. An increase in the unemployment rate increases the probability of outflow from unemployment to inactivity. Interesting conclusions arise with respect to the impact of benefits on discouragement from job search. All models show that benefits increase the probability of withdrawing from job search. This conclusion arises regardless of the fact that the workers are already receiving the benefit or are to receive it within a one year period. Among those who do not receive old-age benefits, if the old-age benefit becomes a source of income, the worker is 4.7 times more likely to refrain from the labour market. If it becomes the main source of income the worker is 6 times more likely to withdraw from job search than those who receive an invalidity allowance, 8 times more than those who receive unemployment benefits, and 20 times more than those who receive social welfare benefits.

The aforementioned qualitative findings are consistent with some of the results from the SHARE analysis. Myck et al. (2014) show that older workers and those who become eligible for old-age benefits are more probable of leaving the labour market. The participation is positively related to health status; yet at the same time health status does not significantly differentiate the timing of the flow to inactivity.

\section{Concluding remarks}

In this paper we present an empirical analysis of the discouraged worker effect among older workers. We broaden the standard definition of this effect to identify to what extent easy and early access to old-age benefits contributes to the widely observed low 
activity rates among older workers. We treat old-age benefits as an alternative source of income to remuneration - either as already available or as a forthcoming option.

We based the quantitative analysis on macroeconomic LFS data (2000-2013) and LFS individual data (2004-2010). Being cautious in the qualitative interpretation of the results, we draw a number of conclusions. Cyclical properties of activity rates vary in time. The discouraged worker effect occurs among older workers but it seems to vary in time as well. The added worker effect prevails at first; the discouraged worker effect arises after some delay. The effect is asymmetric in intensity and length. A larger effect occurs after a negative shock arises, with more people leaving the workforce than re-entering the labour market once job finding opportunities improve. Moreover, workers leave the workforce almost permanently. Interestingly, in the short-term, when employment opportunities improve, the workers leave the workforce as well.

Females and older workers are more likely to withdraw from labour market participation. An increase in the unemployment rate and old-age benefits also discourage them from seeking work. Workers who receive old-age benefits (and treat them as the main source of income) are 8 to 20 times more likely to leave the workforce compared to those who receive either unemployment benefits or social welfare benefits.

Budgetary constraints and their projections are usually put forward in debates on the retirement age and the need to raise it. There are good reasons for that, although the public hardly agrees with that need. Despite the fact that the data we have do not permit us to draw strong conclusions, our paper is a minor contribution to the complexity of arguments for a higher retirement age, understood as the age of availability of old-age benefits. The benefits seem to contribute to premature withdrawal from the labour market, which means not only an increased fiscal burden but also a welfare loss. This argument goes beyond purely fiscal 
arguments and may help in encouraging people to stay in employment rather than retiring, even after reaching the retirement age. 


\section{References}

1. Benati L. (2001), Some empirical evidence on the 'discouraged worker' effect, Economics Letters, 70, 387-395.

2. Benitez-Silva H. (2002), Job Search Behavior at the End of the Life Cycle, Center for Retirement Research at Boston College WP 2002-10, December.

3. Clark K., Summers L. (1982), Labor Force Participation: Timing and Persistence, The Review of Economics Studies, vol. 49, no. 5, Special Issue on Unemployment, 825-844.

4. Connolly G. (1997), The Influence in Reducing the Male Full-time Unemployment Rate in Australia, paper presented to the $26^{\text {th }}$ Conference of Economists, University of Tasmania, 27-29 September 1997.

5. Darby J., Hart R., Vecchi M. (1998), Labour Force Participation and the Business Cycle: A Comparative Analysis of Europe, Japan and the United States, Working Papers 9802, Business School - Economics, University of Glasgow.

6. Enders W., Granger C. (1998), Unit-Root Tests and Asymmetric Adjustment With an Example Using the Term Structure of Interest Rates, Journal of Business and Economic Statistics 16, 304-311.

7. Enders W., Siklos P. (2001), Co-integration and Threshold Adjustment, Journal of Business and Economic Statistics 19, 166-177.

8. Gałecka-Burdziak E., Pater R. (2014), Discouraged worker effect - evidence for Poland, manuscript.

9. Góra M. (2013), Political economy of pension reforms: selected general issues and the Polish pension reform case, IZA Journal of Labour \& Development 2013, 2:2 (doi:10.1186/2193-90202-2) http://www.izajold.com/content/pdf/2193-9020-2-2.pdf

10. Gruber, J., D. A. Wise (ed.) (1999), Social Security and Retirement Around the World, University of Chicago Press.

11. van Ham M., Mulder C. H., Hooimeijer P. (2001), Local underemployment and the discouraged worker effect, Urban Studies, September, 38, 10, 1733-1751. 
12. Maestas N., Li X. (2006), Discouraged Workers? Job Search Outcomes of Older Workers, University of Michigan Retirement Research Center Working Paper WP 2006-133.

13. Myck M., Najsztub M., Oczkowska M. (2014), Dynamika rynku pracy i zmiany w sytuacji materialnej osób w wieku 50+, [in:] Chłoń-Domińczak A. (ed.) Portret generacji 50+ w Polsce i Europie. Wyniki badania zdrowia, starzenia się i przechodzenia na emeryturę w Europie (SHARE), Instytut Badań Edukacyjnych, Warszawa http://ibmed.ayz.pl/share/files/publikacje/ibe-raport-krajowy-SHARE.pdf.

14. O'Brien M. (2011), Discouraged Older Male Workers and the Discouraged Worker Effect, Australian Journal of Labour Economics, 14 (3), 217-235.

15. Saint-Paul, G. (2004), Why are European Countries Diverging in their Unemployment Experience?, Journal of Economic Perspectives 18, no. 4 (Fall 2004), 49-68. 


\section{Appendix}

Table 9. The main statistical properties of variables, $1999-2013$.

\begin{tabular}{|l|c|c|c|c|c|c|c|c|}
\hline & $\begin{array}{c}\text { male } \\
\text { activity } \\
\text { rate 45 } \\
-64\end{array}$ & $\begin{array}{c}\text { male } \\
\text { activity } \\
\text { rate 45+ }\end{array}$ & $\begin{array}{c}\text { female } \\
\text { activity } \\
\text { rate 45 } \\
59\end{array}$ & $\begin{array}{c}\text { female } \\
\text { activity } \\
\text { rate 45+ }\end{array}$ & $\begin{array}{c}\text { male } \\
\text { discouraged } \\
\text { worker rate } \\
45-64\end{array}$ & $\begin{array}{c}\text { male } \\
\text { discourag } \\
\text { ed worker } \\
\text { rate 45+ }\end{array}$ & $\begin{array}{c}\text { female } \\
\text { discourage } \\
\text { d worker } \\
\text { rate 45 - } \\
59\end{array}$ & $\begin{array}{c}\text { female } \\
\text { discouraged } \\
\text { worker rate } \\
45+\end{array}$ \\
\hline Mean & 0.662 & 0.495 & 0.604 & 0.331 & 0.024 & 0.018 & 0.037 & 0.034 \\
\hline Median & 0.658 & 0.495 & 0.599 & 0.334 & 0.023 & 0.017 & 0.037 & 0.033 \\
\hline $\begin{array}{l}\text { Stand. } \\
\text { Deviation }\end{array}$ & 0.014 & 0.008 & 0.036 & 0.011 & 0.003 & 0.002 & 0.007 & 0.006 \\
\hline $\begin{array}{l}\text { Monthly } \\
\text { autocorr. }\end{array}$ & 0.884 & 0.933 & 0.940 & 0.890 & 0.773 & 0.742 & 0.856 & 0.866 \\
\hline Min & 0.642 & 0.481 & 0.549 & 0.302 & 0.019 & 0.014 & 0.023 & 0.023 \\
\hline Max & 0.695 & 0.508 & 0.681 & 0.347 & 0.031 & 0.023 & 0.052 & 0.048 \\
\hline $\begin{array}{l}\text { No. of } \\
\text { observations }\end{array}$ & 56 & 56 & 56 & 56 & 56 & 56 & 56 & 56 \\
\hline
\end{tabular}

Source: LFS, data seasonally adjusted, authors' calculations.

Table 10. Correlation coefficients between cyclical components of male and female activity rates, male and female discouraged workers rates and lagged GDP and unemployment rate computed on the basis of the HP filter estimates.

\begin{tabular}{|c|c|c|c|c|c|c|c|c|}
\hline \multirow[b]{2}{*}{ Variable } & \multicolumn{8}{|c|}{ Hodrick-Prescott filter } \\
\hline & $\begin{array}{l}\text { male } \\
\text { activity } \\
\text { rate } 45-64\end{array}$ & $\begin{array}{l}\text { male } \\
\text { activity } \\
\text { rate } 45+\end{array}$ & $\begin{array}{l}\text { female } \\
\text { activity } \\
\text { rate } 45-59\end{array}$ & $\begin{array}{l}\text { female } \\
\text { activity } \\
\text { rate } 45+\end{array}$ & $\begin{array}{l}\text { male } \\
\text { discouraged } \\
\text { worker rate } \\
45-64\end{array}$ & $\begin{array}{l}\text { male } \\
\text { discouraged } \\
\text { worker rate } \\
45+\end{array}$ & $\begin{array}{l}\text { female } \\
\text { discouraged } \\
\text { worker rate } \\
45-59\end{array}$ & $\begin{array}{l}\text { female } \\
\text { discouraged } \\
\text { worker rate } \\
45+\end{array}$ \\
\hline$G D P_{-1}$ & $-0,193$ & 0,050 & $-0,302$ & $-0,193$ & $-0,235$ & $-0,280^{*}$ & 0,159 & 0,068 \\
\hline$G D P_{-2}$ & $-0,038$ & 0,134 & $-0,141$ & $-0,115$ & $-0,295^{*}$ & $-0,337 * *$ & 0,176 & 0,054 \\
\hline$G D P_{-3}$ & 0,025 & 0,142 & $-0,032$ & $-0,031$ & $-0,343 * *$ & $-0,382 * *$ & 0,244 & 0,093 \\
\hline$G D P_{-4}$ & 0,146 & 0,046 & 0,013 & $-0,070$ & $-0,384 * *$ & $-0,420 * * *$ & $0,323 * *$ & 0,145 \\
\hline$G D P_{-5}^{-4}$ & 0,144 & $-0,026$ & 0,076 & $-0,036$ & $-0,425 * * *$ & $-0,451 * * *$ & $0,335 * *$ & 0,134 \\
\hline$G D P_{-6}$ & 0,066 & $-0,137$ & 0,168 & 0,043 & $-0,461 * * *$ & $-0,475 * * *$ & $0,296^{*}$ & 0,077 \\
\hline$G D P_{-7}$ & $-0,008$ & $-0,241$ & 0,206 & 0,002 & $-0,485 * * *$ & $-0,491 * * *$ & $0,265^{*}$ & 0,034 \\
\hline$G D P_{-8}$ & $-0,185$ & $-0,323$ & 0,204 & 0,017 & $-0,514 * * *$ & $-0,505 * * *$ & 0,151 & $-0,089$ \\
\hline$G D P_{-9}$ & $-0,234$ & $-0,289$ & $0,287^{*}$ & 0,156 & $-0,537 * * *$ & $-0,508 * * *$ & $-0,035$ & $-0,279 *$ \\
\hline$G D P_{-10}$ & $-0,224$ & $-0,262$ & $0,364 * *$ & $0,262 *$ & $-0,542 * * *$ & $-0,503 * * *$ & $-0,153$ & $-0,395 * * *$ \\
\hline$G D P_{-11}$ & $-0,257$ & $-0,256$ & $0,376^{* *}$ & $0,304 * *$ & $-0,529 * * *$ & $-0,479 * * *$ & $-0,268 *$ & $-0,500 * * *$ \\
\hline$G D P_{-12}$ & $-0,260$ & $-0,158$ & $0,449 * * *$ & $0,440 * * *$ & $-0,484 * * *$ & $-0,428 * * *$ & $-0,299 * *$ & $-0,513 * * *$ \\
\hline$u_{-1}$ & 0,219 & 0,249 & $0,446 * * *$ & $0,397 * * *$ & 0,186 & 0,248 & $-0,174$ & $-0,111$ \\
\hline$u_{-2}$ & 0,197 & 0,208 & $0,298 * *$ & 0,248 & $0,307 * *$ & $0,364 * *$ & $-0,131$ & $-0,015$ \\
\hline$u_{-3}$ & 0,180 & 0,204 & 0,160 & 0,149 & $0,426 * * *$ & $0,474 * * *$ & $-0,084$ & 0,086 \\
\hline$u_{-4}$ & 0,168 & 0,191 & 0,017 & 0,083 & $0,538 * * *$ & $0,574 * * *$ & $-0,036$ & 0,184 \\
\hline$u_{-5}$ & 0,168 & 0,172 & $-0,123$ & $-0,020$ & $0,636 * * *$ & $0,661 * * *$ & 0,012 & $0,278^{*}$ \\
\hline$u_{-6}$ & 0,165 & 0,132 & $-0,262^{*}$ & $-0,152$ & $0,718 * * *$ & $0,730 * * *$ & 0,059 & $0,362 * *$ \\
\hline$u_{-7}$ & 0,163 & 0,106 & $-0,382 * *$ & $-0,277^{*}$ & $0,780 * * *$ & $0,780 * * *$ & 0,105 & $0,436^{* * *}$ \\
\hline$u_{-8}$ & 0,170 & 0,082 & $-0,447 * * *$ & $-0,367 *$ & $0,818 * * *$ & $0,804 * * *$ & 0,154 & $0,504 * * *$ \\
\hline$u_{-9}$ & 0,195 & 0,089 & $-0,509 * * *$ & $-0,413 * * *$ & $0,823 * * *$ & $0,794 * * *$ & 0,202 & $0,558 * * *$ \\
\hline$u_{-10}$ & 0,234 & 0,100 & $-0,575 * * *$ & $-0,471 * * *$ & $0,799 * * *$ & $0,755^{* * *}$ & 0,238 & $0,587 * * *$ \\
\hline$u_{-11}$ & 0,235 & 0,051 & $-0,598 * * *$ & $-0,505 * * *$ & $0,752 * * *$ & $0,699 * * *$ & 0,248 & $0,580 * * *$ \\
\hline$u_{-12}$ & 0,228 & $-0,015$ & $-0,611 * * *$ & $-0,610 * * *$ & $0,682 * * *$ & $0,623 * * *$ & 0,239 & $0,545 * * *$ \\
\hline
\end{tabular}

* - significant at the 10 per cent level, ** - significant at the 5 per cent level, *** - significant at the 1 per cent level.

Source: authors' calculations. 